\title{
The Origin and Spread of Early-Ripening Champa Rice: It's Impact on Song Dynasty China
}

\author{
Randolph Barker
}

Received: 5 October 2011 / Accepted: 12 December 2011 /Published online: 17 January 2012

(C) Springer Science+Business Media, LLC 2012

\begin{abstract}
Often overlooked is the importance of earlymaturing rice varieties with their ability to escape droughts, avoid floods, and in some localities, open up the opportunity for double cropping. Most varieties grown in the tropics until the last half century matured in 150 to 180 days or longer and were photoperiod sensitive. However, non-photoperiod sensitive one-hundred-day varieties were grown in the Champa Kingdom in what is now Central Vietnam centuries ago. How these varieties moved into Song Dynasty China and the impact of the earlyripening rice on population growth in South China is well documented. However, the origin of the Champa varieties is less clear. According to a recent DNA test (see below), the Champa varieties belong to the aus sub-population. The aus have the characteristics of both indica and japonica and originated in the hill areas of what are now Eastern India, Bangladesh, and Myanmar. Because the Champa Kingdom adopted the Indian language and religion, at least in the higher courts, it seems logical that the Champa rice must have been disseminated from the hilly areas in the Indian sub-continent to Central Vietnam and eventually to China-first Fujian and later to the Yangtze region during the Song Dynasty in the eleventh century.
\end{abstract}

\footnotetext{
R. Barker $(\bowtie)$

Department of Applied Economics and Management, Cornell University,

106 Warren Hall,

Ithaca, NY 14850, USA

e-mail: rb19@cornell.edu
}

Keywords Early-Ripening Rice - Aus Rice Varieties · Champa Kingdom · Song Dynasty

\section{Background}

The origin and spread of Champa rice took place centuries ago when rice varieties were typically selected and developed by farmers for their suitability to a particular environmental situation. This would include resistance or tolerance to abiotic stresses - temperature (hot or cold), flooding, drought, salinity. The objective was one of food security where, in much of Asia, rice had become the staple food. But advances in varietal improvement have through time carried a doubleedged sword-facilitating food security and alleviating poverty in the short run, but inadvertently serving as a catalyst for further human population growth.

Recently, the clear path to increased rice production has been through adoption of modern high-yielding varieties, coupled with irrigation expansion and with greater use of chemicals - fertilizer, herbicides, pesticides. This led to the so-called green revolution in Asia, which was threatened by a population explosion after World War II.

However, sparked in part by concerns over global warming, attention is now being given to varieties that will perform well in more diverse environmental settings such as found in the unirrigated areas which account for approximately half of the Asian rice acreage. Varieties found in these areas are referred to as upland. They are exposed to a variety of adverse factors such as the abiotic stresses noted above. Paradoxically, this brings us to the story of the Champa rice which took place centuries ago. 


\section{Song Dynasty China (960-1279AD)}

Agricultural technology in north China developed well ahead of other regions of China. From the fourth century onward, however, there was a steady migration southward, particularly into the Yangtze area (Ho 1956). The rapid expansion of rice cultivation in southeast China was aided by large-scale production of iron tools. Factors crucial to the expansion and improvement of rice cultivation were water control, farm implements, draft animals, planting methods, weed and pest control, manuring, seed selection, and, above all, human innovation (Chang 2000).

The continued development of the rice area led to a revolution in agriculture not unlike the modern-day green revolution. Faced with growing population pressure on the land, the early Song emperors repeatedly exhorted the nation to improve food crops and to experiment with new ones (Ho 1956).

There was a severe drought in the Yangtze and Huai river valley areas and in the eastern and western Zhejiang paddy rice areas in 1012. The emperor Zhenzong (992-1022) came to know that Champa rice was drought resistant, early maturing, and non-photoperiod sensitive (Sharma 2010) (that is to say, its ripening was not determined by the day length or period of sunlight). Special envoys were sent to Fujian Province to procure 30,000 bushels of seed and distribute this to farmers in the drought areas together with government instructions as to the proper method of cultivation (Ho 1956). The rice came to China from the Champa Kingdom in what is now central Vietnam. No one knows when the Champa rice arrived in Fujian. Some say it was as early as the eighth century, but from 1012 onward, Champa rice began to receive widespread attention in China (Ho 1956).

The Champa rices, unlike the popular varieties of the time, at first gave lower yields than most traditional Chinese varieties. But farmers selected and developed higheryielding varieties to grow in the well-watered lowland fields (Bray 1986).

\section{Champa Kingdom (seventh to fifteenth centuries)}

The Cham people descended from Malayo-Polonyesian settlers who arrived in the mainland from Borneo around the second and first century BC (Thurgood 1999). Their language was part of the Austronesian family and according to one study related most closely to modern Achenese (Thurgood 1999). The Chams were also seafaring people dedicated to trade.

There is much discussion in the literature about the influence of India on Champa, the so-called hinduized or indianized kingdoms of Champa and other states in Southeast Asia. Hall (1981) warns, however, that the spread of language and religion was typically confined to the royal courts and did not greatly affect the indigenous culture. The Cham courts had adopted the Sanskrit language and Hindu and later Buddhist religions. But what was recorded by the monks or discovered by the archeologists must be regarded as a biased sample. The mundane life of the peasants, including how the population fed itself, was not a subject of great interest.

That having been said, however, whether by word of mouth, through trade or by other means, rice technologies developed by farmers over centuries in southern China spread in part into Southeast Asia (Ho 1956). In the 1960s, most Philippine rice farmers were using a Chinese comb tooth harrow in the preparation of their paddy fields for transplanting. The harrow and the hitch to the water buffalo were essentially identical to that used in Song Dynasty China in the later Han Dynasty (200 BC to $220 \mathrm{AD}$ ) (see Bray 1984).

Champa rice is an aus variety (Sweeney et al. 2007; cf. map on e133). Ho (1956) notes that there was considerable question in the literature as to whether Champa rice is of upland or lowland origin. He states that the problem is so complex that "any clear cut answer seems" impossible. Upland rice is exposed to many adverse factors that may not be found in lowland, paddy field conditions. These include abiotic stresses such as drought, flooding, adverse soils, and temperatures (IRRI 1975). Some of the upland varieties have adapted to these adverse conditions.

Several months ago, I asked Susan McCouch, Cornell geneticist and rice breeder, if she had heard of Champa rice. She said she would look in her gene bank. A few days later, she said that she had found a Champa variety, run a DNA test, and said it was an aus. Aus is one of five sub-populations of Oryza sativa-the other four being indica, temperate japonica, tropical japonica, and aromatic (Kovach et al. 2007). While similar to indica, aus varieties have distinctly different traits such as drought tolerance and non-photoperiod sensitivity.

The above finding answers two important questions. First, modern genetics answered the question which Ho a half century earlier could not answer. That is to say Champa rice is an upland variety. Second, the aus subpopulation had its origin in the uplands of what are now Eastern India, Bangladesh, and Myanmar (Sweeney et al. 2007). These Champa rices which almost certainly must have first been developed in eastern India found their way eastward into the hilly areas of what is today central Vietnam and then northward to Fujian and later the Yangtze region of China. 


\section{Impact of early-ripening rice in China}

It has been argued by Ho (1956) that the introduction of Champa rice to China and the attention given to the adoption of this rice by the Song Dynasty emperors marked the beginning of the spread of the early-ripening varieties. Perkins (1969) and Zeng (1998) question this, the latter arguing that not well-publicized domestic hsien (indica) varieties were better suited to the lowlands while the Champa was suited to the highlands. Ho (1956) acknowledges that the distinction between indigenous hien and introduced champa became less and less clear over time, to the point that by the Ming times (fourteenth to seventeenth centuries), the terms had become identical.

There is a general consensus, however, that increase in rice production through both terracing of the uplands and expansion of double cropping in the irrigated lowlands solved an immediate food security problem, but encouraged migration and a further population increase in the southern China rice-growing areas.

\section{Epilogue}

The importance of traits contained in the aus varieties like early ripening cannot be overstated. Garris et al. (2005) note that although the aus varietal types have received less attention than japonica or indica in breeding program, aus drought tolerance and early maturity are adaptive traits that could usefully be targeted in breeding applications.

In the past half century, the green revolution led to the rapid increase in rice production particularly in the wellirrigated lowlands at least temporarily solving Asia's food security problem. The first of the early-maturing 100-day varieties for the tropical lowlands, IR36, was released by the International Rice Research Institute in 1976. While some applauded the fact that IR 36 was so widely adopted, other scientists were concerned that the lack of diversity in the cytoplasm posed a risk in terms of outbreak of disease and insects. Also, paradoxically, as this technology has become fully exploited, food security is again becoming a concern.
For the reasons above, and as we enter an era of water scarcity in much of Asia and are concerned with climate change, scientists are giving increased attention to the development of varieties that perform well under adverse environmental conditions. Greater research emphasis is now being given to the search for genes that would give rice varieties a tolerance to abiotic stresses such as drought, floods, and salinity. The upland varieties such as those found in the aus sub-population represent a potential source for such genes. In short, the traits sought by today's rice breeders are much the same as those that farmers and emperors sought in Song Dynasty China.

\section{References}

Bray F. Agriculture. Vol. VI Part 2. In: Needham J, editor. Science and civilization in China. Cambridge: Cambridge University Press; 1984.

Bray F. The rice economies: technology and development in Asian Societies. Oxford: Basil Blackwell Ltd.; 1986.

Chang T-T. Rice, economic and biological importance. In: Kiple KF, Ornelas KC, editors. The Cambridge world history of food. Cambridge: Cambridge University Press; 2000.

Garris AJ, Tai TH, Coburn J, Kresovich S, McCouch S. Genetic structure and diversity in Oryza sativa L. Genetics. 2005;169:1631-8.

Hall DGE. History of South-East Asia. New York: St. Martin's Press; 1981.

Ho P-T. Early-ripening rice in Chinese history. Economic History Review New series. 1956;9(2):200-18.

International Rice Research Institute. Major research in upland rice. Annual report. Los Banos: IRRI; 1975.

Kovach MJ, Sweeney MT, McCouch SR. New insights into the history of rice domestication. Trends Genet. 2007;23(11):578-87.

Perkins D. Agricultural development in China 1368-1968. Chicago: Aldine; 1969.

Sharma SD. Rice: origin, antiquity, and history. Enfield: Science Publishers; 2010.

Sweeney MT, Thompson MJ, Chou YG, Park YJ, Williamson SH, Bustamante CB, McCouch SR. Global dissemination of a single mutation conferring white pericarp in rice. PLoS Genet. 2007;3 (8):e133.

Thurgood G. From ancient cham to modern dialects. Honolulu: University of Hawaii Press; 1999.

Zeng X. Huang-lu rice in Chinese history. Agric Archaeol. 1998;3:292_ 311. 